Journal Homepage: $-\underline{w w}$.journalijar.com
ISSN NO. 2320-5407

RESEARCH ARTICLE

\title{
AWARENESS OF PEOPLE ABOUT MISUSE AND SELF-MEDICATION WITH ANTIBIOTICS IN HAIL REGION, KSA.
}

\author{
Madiha R. Mahmoud ${ }^{1}$, Kholoud KM Almowald ${ }^{2}$,Ahlam AN Alsuhaymi ${ }^{2}$, Zainab AM Alzayer ${ }^{2}$, Rahaif HJ \\ Aljishi $^{2}$ and Maryam KA Albahar ${ }^{2}$ \\ 1. Pharmacology Department, College of Medicine, Hail University, P.O. Box 2440, Hail, KSA. \\ 2. College of Medicine, Hail University, P.O. Box 2440, Hail, KSA.
}

\section{Manuscript Info}

\section{Manuscript History}

Received: 10 January 2019

Final Accepted: 12 February 2019

Published: March 2019

Key Words:-

Antibiotics resistance, Antibiotics misuse, self-medication, Hail region, Saudi Arabia.

\section{Abstract}

Background: The misuse of antibiotics is a major public health problem. This misuse results in another major problem which is bacterial resistance to many known antibiotics. This problem rather than being global, it is also a great concern in the kingdom of Saudi Arabia.

Objectives: The aim of this study is to evaluate public awareness of the misuse of antibiotics in Hail region, Saudi Arabia.

Methods: we conducted a cross-sectional study using online survey in Hail region and was distributed to the residents of the city. We started collecting data on November $15^{\text {th }}, 2018$ for one week. Out of the city residents 204 people participated in the survey. The questionnaire was randomly distributed and involved socioeconomic characteristics and Questions aimed to measure knowledge about the antibiotic side effects, resistance and its effect on the immunity. Results: Most participants were female ( $70.1 \%$ females and $29.9 \%$ males). The level of education varied from university (75.9\%), from secondary school $(20.6 \%)$. The participants were asked if they ever administered antibiotics without prescription, $43.6 \%$ said sometimes, $22.06 \%$ (never), $19.6 \%$ (rarely) and $14.7 \%$ said always. Also, $49.5 \%$ of participants did not complete the course of antibiotics, while $24.5 \%$ always did not complete the course, but never for $8.8 \%$ and $17.2 \%$ said rarely. Concerning the knowledge of participants about the cause of antibiotic resistance and weak response of the antibiotics, the answers varied, $40.2 \%$ said due to uncomplete the antibiotic course, while $29.9 \%$ did not know, $23.5 \%$ said taking antibiotics without need.

Conclusion: The majority of illness people in Hail are seeking selfmedication with antibiotics could be probably of viral origin and unnecessary use of antibiotics promote the emergence of new-strains of resistant pathogens and the incidence of unwanted adverse effects. Recommendations: Health authorities advised to take serious steps to put an approved law for no antibiotics without prescription. In addition, health awareness campaigns advised to prevent antibiotic misuse. Also, the pharmacists could play an important role in educating patients about antibiotic use in the society.

Corresponding Author:- Madiha R. Mahmoud.

Address:- Pharmacology Department, College of Medicine, Hail University, P.O. Box 2440, Hail, KSA. 


\section{Introduction:-}

Self-medication with antibiotics is defined as the acquisition of antibiotics and self-administering them [or administering them to the children] with the aim of treating a perceived infection. ${ }^{[1]}$ Despite of WHO efforts in halting the overuse of antimicrobials, antimicrobial purchase is considered one of the most common buying medications globally. ${ }^{[2]}$ The purchase of antimicrobial drugs without prescription is estimated to be $58 \%$ in Asia, $47 \%$ in southern Europe, $30 \%$ in eastern Europe, $25 \%$ in South America, 39\% in Middle East. ${ }^{[3]}$ The presence of antibiotics as a prescription-only-medicine does not exclude a possibility that they can be used for self-medication. For this purpose, antibiotics can be obtained as the leftovers of the pharmaceuticals from an incomplete course of treatment, or can be supplied by friends or relatives. Some patients insist that the physician should write a prescription for antibiotics for them. ${ }^{[1]}$ Most of the people think that antibiotics are effective for common cold. Mostly people of developing countries think that even for minor common cold and flu like symptoms antibiotics are best choice and use on the basis of self-medications. Another study has shown that most of the people don't follow complete course of antibiotics because they feel better. ${ }^{[4]}$ Inappropriate prescribing of antibiotics has been attributed to a number of causes including people who insist on antibiotics, physicians who simply prescribe them as they feel they do not have time to explain why they are not necessary, physicians who do not know when to prescribe antibiotics or else are overly cautious for medico-legal reasons and those who just prescribe for economic reasons. ${ }^{\text {[5] }}$ No data estimated the economic burden of antibiotic resistance in Saudi Arabia; however, in the United States, approximately a range from $\$ 18,588$ to $\$ 29,069$ is the medical cost of a patient with antibiotic resistance infection. ${ }^{\text {[6] }}$ Antimicrobial resistance in bacteria is emerging and spreading rapidly worldwide. ${ }^{[7]}$ Kingdom of Saudi Arabia showed the highest prevalence of resistant pathogens in clinical isolates among all Gulf Corporation Council (GCC) countries. ${ }^{[8]}$ Therefore, the aim of this cross sectional study is to evaluate the knowledge and behaviour toward antibiotic self-medication among adults living in the community of Hail, Saudi Arabia.

\section{Materials and Methods:-}

\section{Sample and study area}

A cross sectional study using survey was conducted during period from $15^{\text {th }}$ November, 2018 for one week, targeting people who are living in Hail region, Saudi Arabia. Data was distributed through online based survey and the questionnaire where made in English and translated to Arabic language to be suitable for the respondent.

\section{Instrument}

The questionnaire consists of 15 closed questions, arranged in 4 subscales. It includes three questions about the demographic characteristics; five questions about knowledges about antibiotics, four questions for knowledges about antibiotic resistance, side effects and effect on patient's immunity, and the last three questions about the basis for choosing certain antibiotics and the types of diseases that receive antibiotics without prescription.

\section{Statistics}

Data was coded, entered, and analysed using the Statistical Package for Social Science (SPSS) version 22.

\section{Results:-}

About 204 participants were responding to the questionnaire (70.1\% females and $29.9 \%$ males). The ages of participants ranged from 16 to 45 years old, most of them (35.8\%) from 21-23-year-old followed by (24.5\%) from 19-20-year-old then (11.3\%) from 16-18-year-old while the least number of participants from 36-45-year-old. The level of education varied from university $(75.9 \%)$, from secondary school $(20.6 \%)$.

Table 1 and Figure 1 showed that $82.4 \%$ of participants know what are the antibiotics, while only $13.7 \%$ (may be know) and only $3.9 \%$ don't know. The source of knowledge about antibiotics varied, most from family (51.9\%), from social media (39.7\%), from their study (34.8\%), from friends $(26.5 \%)$ and from books and readings (15.2\%). The answers on the $5^{\text {th }}$ question that if you administered antibiotics without prescription, $43.6 \%$ said sometimes, $22.06 \%$ (never) , $19.6 \%$ (rarely) and $14.7 \%$ said always. Only $37.7 \%$ always read the internal pamphlet, while 28.4 (sometimes), never $(18.1 \%)$ and rarely $(15.7 \%)$. Also, $49.5 \%$ of participants did not complete the course of antibiotics, while $24.5 \%$ always did not complete the course, but never for $8.8 \%$ and $17.2 \%$ said rarely. 
Table 1:-Numbers and percentages of participant knowledge's about antibiotics questions and responses in $(\mathrm{n}=204)$, in Hail region, Saudi Arabia.

\begin{tabular}{|c|c|c|c|c|c|c|}
\hline \multirow{3}{*}{$\begin{array}{l}\text { Question } \\
\text { 1- Do you know antibiotics? }\end{array}$} & \multicolumn{6}{|c|}{ n (\%) } \\
\hline & YES & NO & \multicolumn{4}{|c|}{ MAY BE } \\
\hline & $\begin{array}{c}168 \\
(82.4)\end{array}$ & $\begin{array}{c}8 \\
(3.9)\end{array}$ & \multicolumn{4}{|c|}{$\begin{array}{c}28 \\
(13.7) \\
\end{array}$} \\
\hline \multirow[t]{2}{*}{$\begin{array}{l}2 \text { - Sources of knowledge } \\
\text { about antibiotics. }\end{array}$} & Family & Friends & $\begin{array}{l}\text { Books \& } \\
\text { readings }\end{array}$ & Study & $\begin{array}{l}\text { Social } \\
\text { Media }\end{array}$ & Others \\
\hline & $\begin{array}{c}106 \\
(51.9) \\
\end{array}$ & $\begin{array}{c}54 \\
(26.5) \\
\end{array}$ & $\begin{array}{c}31 \\
(15.2) \\
\end{array}$ & $\begin{array}{c}71 \\
(34.8) \\
\end{array}$ & $\begin{array}{c}81 \\
(37.7) \\
\end{array}$ & $\begin{array}{c}9 \\
(4.4) \\
\end{array}$ \\
\hline \multirow{2}{*}{$\begin{array}{lr}3 \text { - If you } & \text { administered } \\
\text { antibiotics } & \text { without } \\
\text { prescription? } & \\
\end{array}$} & Always & Sometimes & Rarely & \multicolumn{3}{|c|}{ Never } \\
\hline & $\begin{array}{c}30 \\
(14.7) \\
\end{array}$ & $\begin{array}{c}89 \\
(43.6) \\
\end{array}$ & $\begin{array}{c}40 \\
(19.6) \\
\end{array}$ & \multicolumn{3}{|c|}{$\begin{array}{c}45 \\
(22.06)\end{array}$} \\
\hline \multirow{2}{*}{$\begin{array}{l}4 \text { - If you read the internal } \\
\text { pamphlet of the antibiotics? }\end{array}$} & Always & Sometimes & Rarely & \multicolumn{3}{|c|}{ Never } \\
\hline & $\begin{array}{c}77 \\
(37.7) \\
\end{array}$ & $\begin{array}{c}58 \\
(28.4) \\
\end{array}$ & $\begin{array}{c}32 \\
(15.7) \\
\end{array}$ & \multicolumn{3}{|c|}{$\begin{array}{c}37 \\
(\mathbf{1 8 . 1}) \\
\end{array}$} \\
\hline \multirow{2}{*}{$\begin{array}{l}5 \text { - If you did not complete } \\
\text { the course of antibiotics? }\end{array}$} & Always & Sometimes & Rarely & \multicolumn{3}{|c|}{ Never } \\
\hline & $\begin{array}{c}50 \\
(24.5)\end{array}$ & $\begin{array}{c}101 \\
(49.5)\end{array}$ & $\begin{array}{c}35 \\
(\mathbf{1 7 . 2})\end{array}$ & \multicolumn{3}{|c|}{$\begin{array}{c}18 \\
(8.8)\end{array}$} \\
\hline
\end{tabular}

n: number of students (\%): Percentage of students

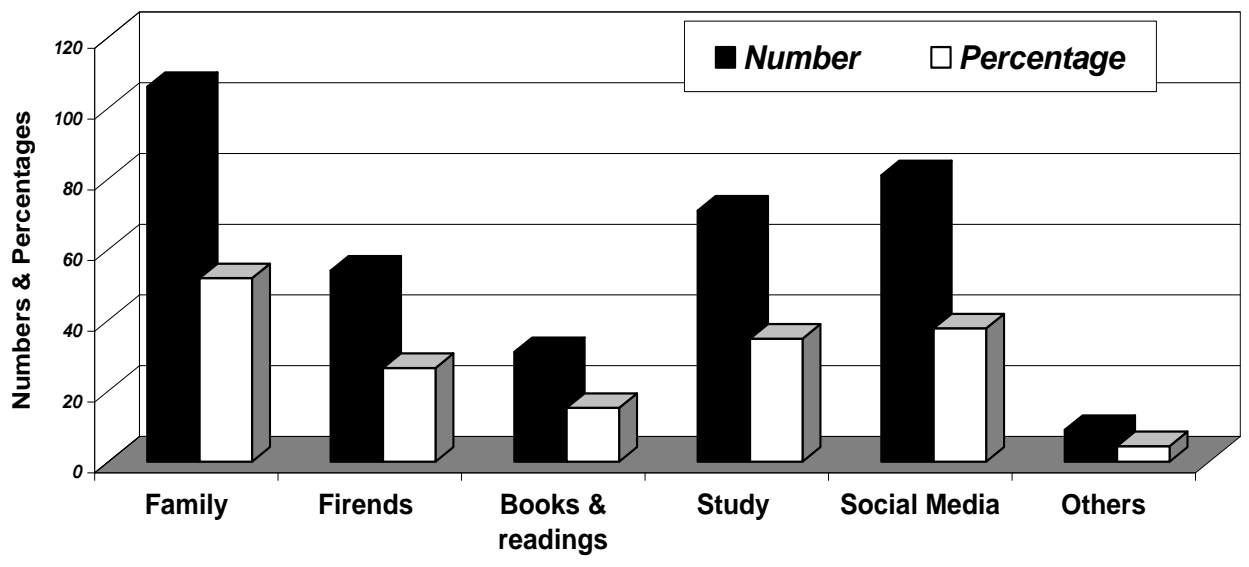

Figure 1. The numbers and percentages of the sources of people knowlege about the antibiotics. 


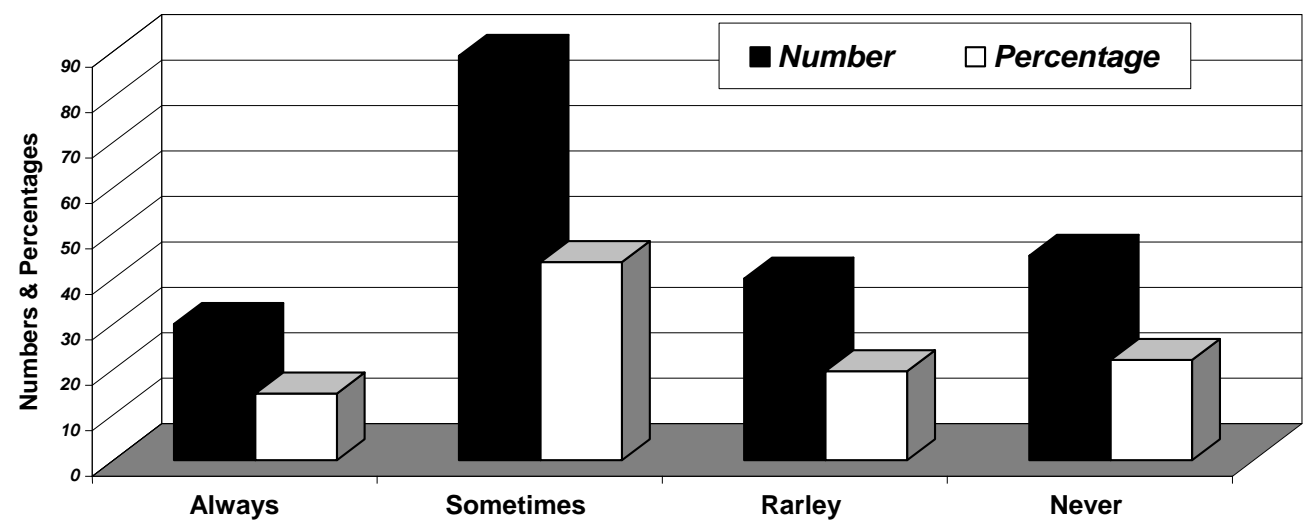

Figure 2. The numbers and percentages of people that adminstered antibiotics without prescription.

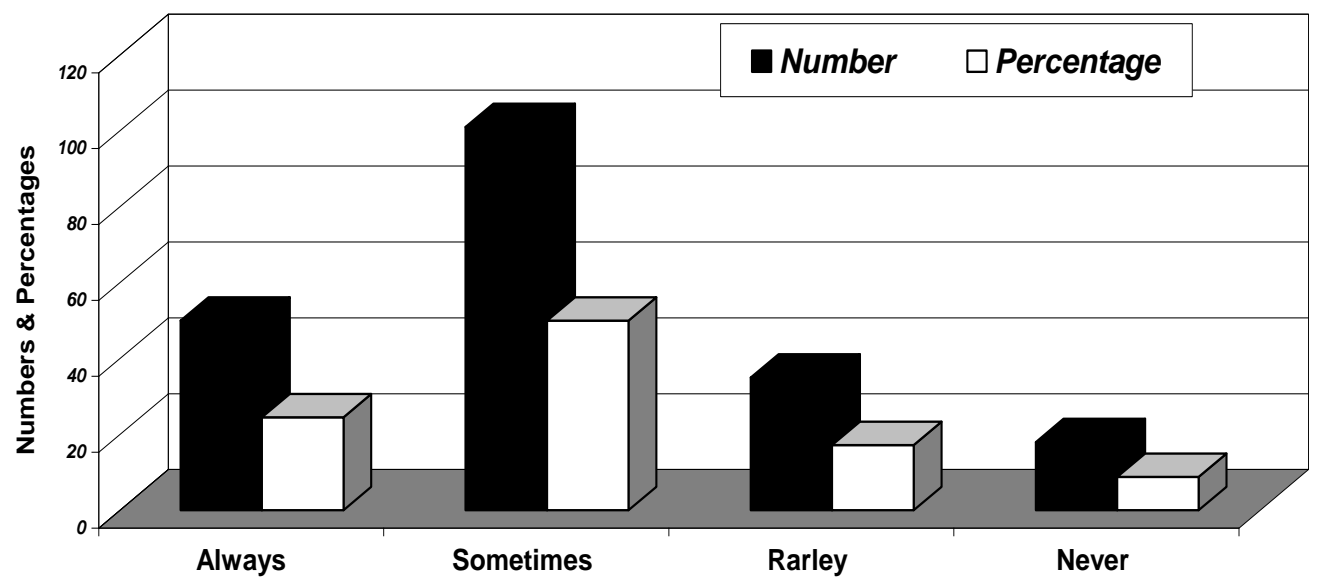

Figure 3. The numbers and percentages of people that answer the questions (If they did not complete the course of antibiotics).

Table 2 and Figure 2 showed that $58.3 \%$ of participants did not change the antibiotics during treatment, while $25.9 \%$ changed it because not effective, $13.2 \%$ changed because of its side effects and $2.5 \%$ changed because of its high cost. Concerning the knowledge of participants about the cause of antibiotic resistance and week response of the antibiotics to treat the patients and kill microorganism, the answers varied, $40.2 \%$ said due to uncomplete the antibiotic course, while $29.9 \%$ did not know, $23.5 \%$ said taking antibiotics without need. The question about the side effects of the antibiotics, $62.3 \%$ (nausea), 34.3\% (diarrhoea), 26.5\% (skin rash) and 25.5\% (vomiting). About the effect of patient immunity, $77.5 \%$ of participants said that antibiotics had negative effect on body immunity, while $18.6 \%$ said (may be), and only $3.9 \%$ said (never).

Table 2:- Numbers and percentages of participant knowledges about the antibiotic side effects, resistance and its effect on the immunity of patients in $(n=204)$, in Hail region, Saudi Arabia.

\begin{tabular}{|c|c|c|c|c|c|}
\hline \multirow{3}{*}{$\begin{array}{l}\text { Question } \\
\begin{array}{l}\text { 6- Did you change } \\
\text { antibiotic the } \\
\text { medication? }\end{array}\end{array}$} & \multicolumn{5}{|l|}{ n (\%) } \\
\hline & $\begin{array}{c}\text { Yes, due to } \\
\text { ineffectiveness }\end{array}$ & $\begin{array}{l}\text { Yes, due to } \\
\text { side effects }\end{array}$ & $\begin{array}{l}\text { Yes, due to } \\
\text { its cost }\end{array}$ & \multicolumn{2}{|c|}{ No change } \\
\hline & $53(25.9)$ & 27 (13.2) & $5(2.5)$ & \multicolumn{2}{|c|}{$119(58.3)$} \\
\hline 7 - What are the common & Skin rash & diarrhea & Vomiting & Nausea & Others \\
\hline
\end{tabular}




\begin{tabular}{|c|c|c|c|c|c|}
\hline $\begin{array}{lll}\begin{array}{l}\text { adverse } \\
\text { antibiotics? }\end{array} & \text { reactions } & \text { of } \\
\end{array}$ & $\begin{array}{c}54 \\
(26.5)\end{array}$ & $\begin{array}{c}70 \\
(34.3)\end{array}$ & $\begin{array}{c}52 \\
(25.5)\end{array}$ & $\begin{array}{c}127 \\
(62.3)\end{array}$ & $\begin{array}{c}26 \\
(12.7)\end{array}$ \\
\hline $\begin{array}{l}8 \text { - Do you know the reason } \\
\text { for antibiotic resistance? }\end{array}$ & Usage without need & $\begin{array}{l}\text { Do not } \\
\text { complete the } \\
\text { course }\end{array}$ & Do not know & \multicolumn{2}{|c|}{ Others } \\
\hline & $48(23.5)$ & $82(40.2)$ & $61(29.9)$ & \multicolumn{2}{|c|}{$13(6.4)$} \\
\hline 9- Are antibiotics affecting & YES & NO & \multicolumn{3}{|c|}{ MAY BE } \\
\hline patient's immunity? & $158(77.5)$ & $8(3.9)$ & \multicolumn{3}{|c|}{38 (18.6) } \\
\hline
\end{tabular}

n: number of students (\%): Percentage of students

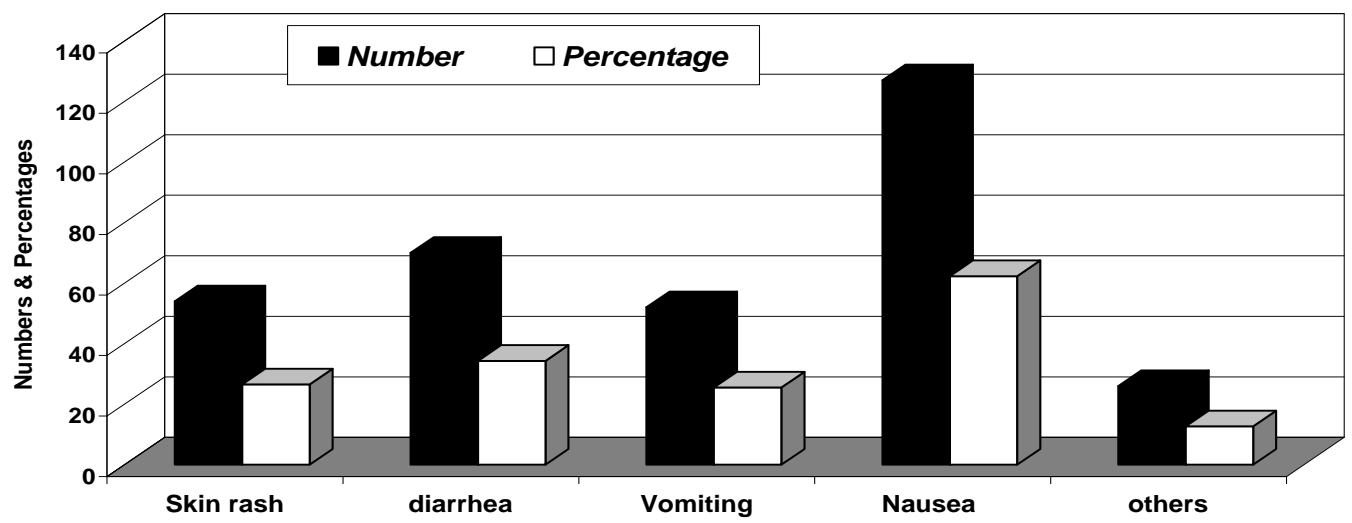

Figure 4. The numbers and percentages of people knowledge about the common adverse reactions of antibiotics.

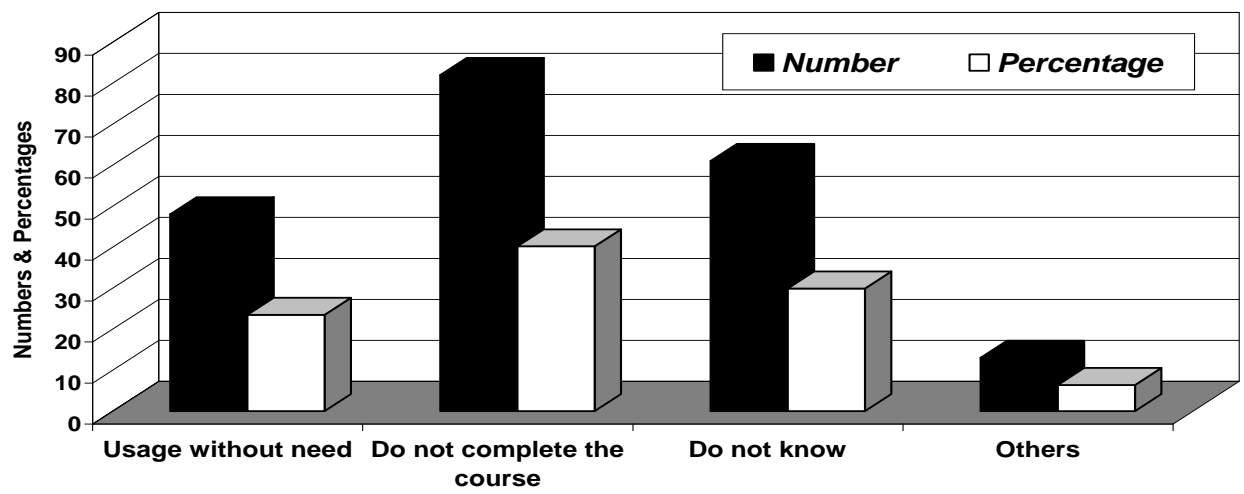

Figure 5. The numbers and percentages of people knowledge about the reason for antibiotic resistance

Table 3 and Figure 3 showed that $69.6 \%$ of participants take antibiotics without prescription because it is easier and more comfortable, $13.2 \%$ because of high cost of physician and $7.2 \%$ because of high cost of antibiotics. The basis that the participants choose certain antibiotics, 50.5\% according to previous prescription, (36.8\% or 36.3\%) according to family or personal use respectively. Many participants take antibiotics without prescription to treat sore throat (52.9\%), congestion and rhinitis (43.6\%), fever (25\%), for treating cough (23.5\%) and for wounds (8.8\%).

Table 3:- Numbers and percentages of participant knowledge's about the basis of choosing antibiotics, and the types of diseases that receive antibiotics without prescription $(n=204)$, in Hail region, Saudi Arabia.

\begin{tabular}{|l|c|c|c|c|}
\hline Question & \multicolumn{3}{|c|}{ n (\%) } \\
\hline $\begin{array}{l}\text { 10- What is the reason of } \\
\text { receiving antibiotics }\end{array}$ & $\begin{array}{c}\text { Easy \& } \\
\text { comfortable }\end{array}$ & $\begin{array}{c}\text { Cost of } \\
\text { physician }\end{array}$ & $\begin{array}{c}\text { Cost of } \\
\text { antibiotics }\end{array}$ & Others \\
\hline
\end{tabular}




\begin{tabular}{|c|c|c|c|c|c|c|}
\hline without prescription? & $\begin{array}{c}142 \\
(69.6)\end{array}$ & $\begin{array}{c}27 \\
(13.2)\end{array}$ & \multicolumn{2}{|c|}{$\begin{array}{l}16 \\
(7.8)\end{array}$} & \multicolumn{2}{|c|}{$\begin{array}{c}19 \\
(9.3)\end{array}$} \\
\hline \multirow{2}{*}{$\begin{array}{l}\text { 11- What is the disease that } \\
\text { you receiving antibiotics } \\
\text { without prescription? }\end{array}$} & $\begin{array}{l}\text { Rhinitis \& } \\
\text { congestion }\end{array}$ & Wounds & Fever & $\begin{array}{c}\text { Sore } \\
\text { throat }\end{array}$ & Cough & Others \\
\hline & $\begin{array}{c}89 \\
(43.6)\end{array}$ & $\begin{array}{c}18 \\
(8.8)\end{array}$ & $\begin{array}{c}51 \\
(25.0)\end{array}$ & $\begin{array}{c}108 \\
(52.9)\end{array}$ & $\begin{array}{c}48 \\
(23.5)\end{array}$ & $\begin{array}{c}31 \\
(15.3)\end{array}$ \\
\hline \multirow[t]{2}{*}{$\begin{array}{l}12 \text { - On what basis you } \\
\text { select the antibiotic? }\end{array}$} & Self experience & $\begin{array}{c}\text { Previous } \\
\text { prescription }\end{array}$ & \multicolumn{2}{|c|}{$\begin{array}{l}\text { Family \& } \\
\text { friends }\end{array}$} & Advertainment & others \\
\hline & $\begin{array}{c}74 \\
(36.3)\end{array}$ & $\begin{array}{c}103 \\
(\mathbf{5 0 . 5})\end{array}$ & \multicolumn{2}{|c|}{$\begin{array}{c}75 \\
(36.8)\end{array}$} & $\begin{array}{c}7 \\
(3.4)\end{array}$ & $\begin{array}{c}23 \\
(11.3)\end{array}$ \\
\hline
\end{tabular}

n: number of students (\%): Percentage of students

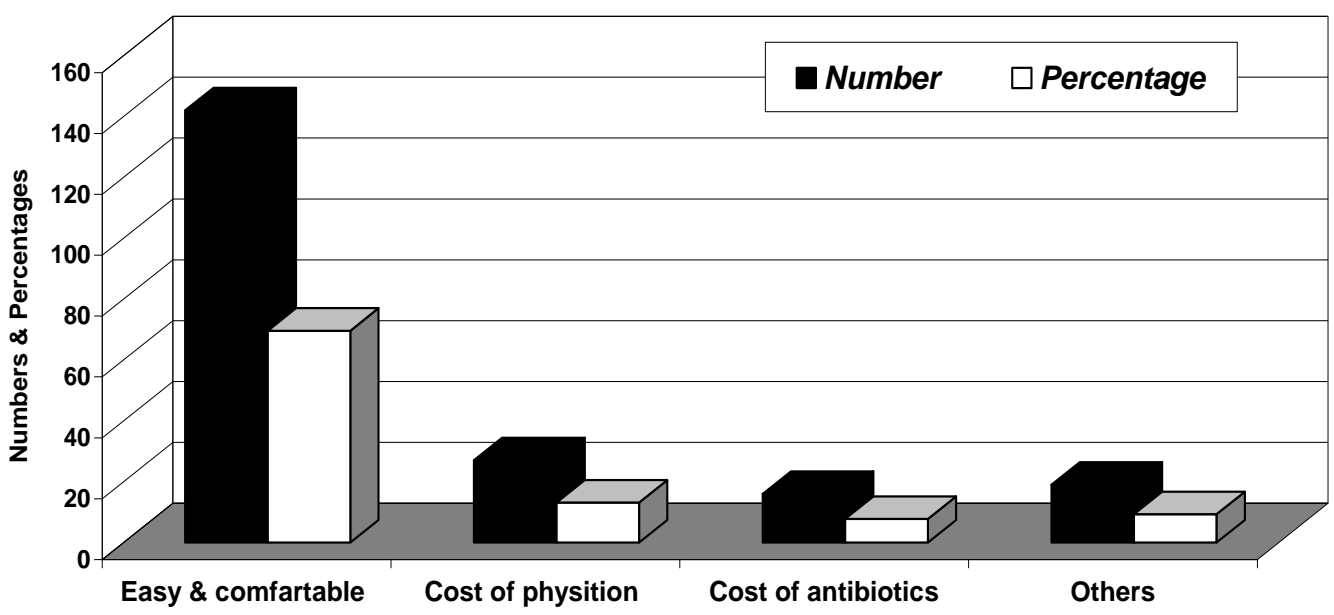

Figure 6. The numbers and percentages of people knowledge about the reason of receiving antibiotics without prescription.

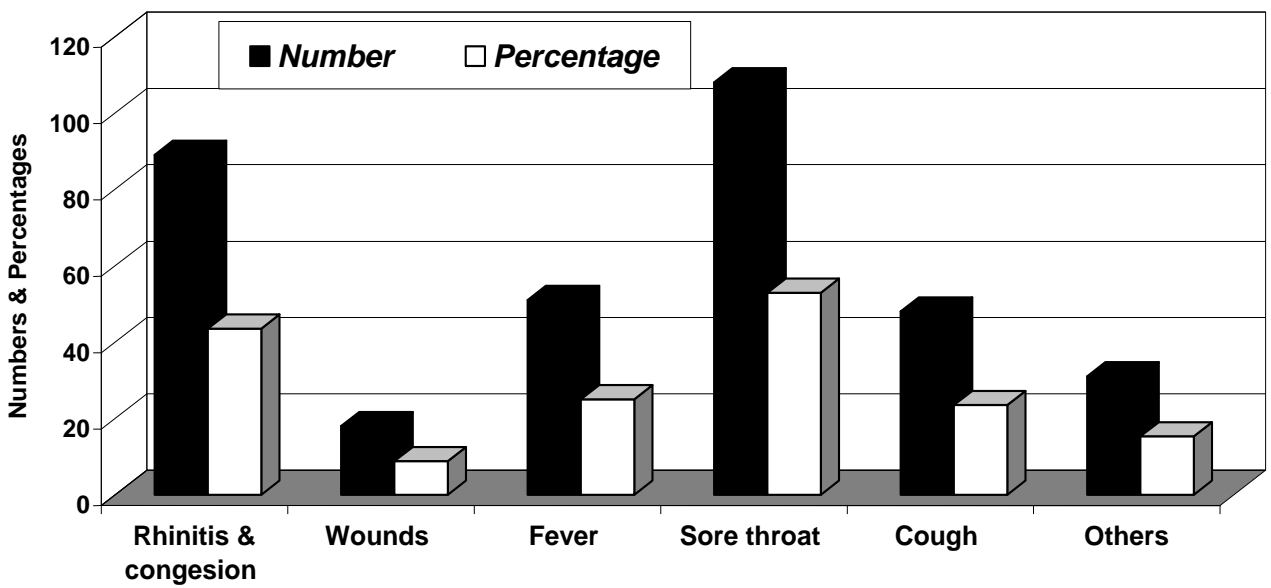

Figure 7. The numbers and percentages of people knowledge about the disease that the pateints receiving antibiotics without prescription. 


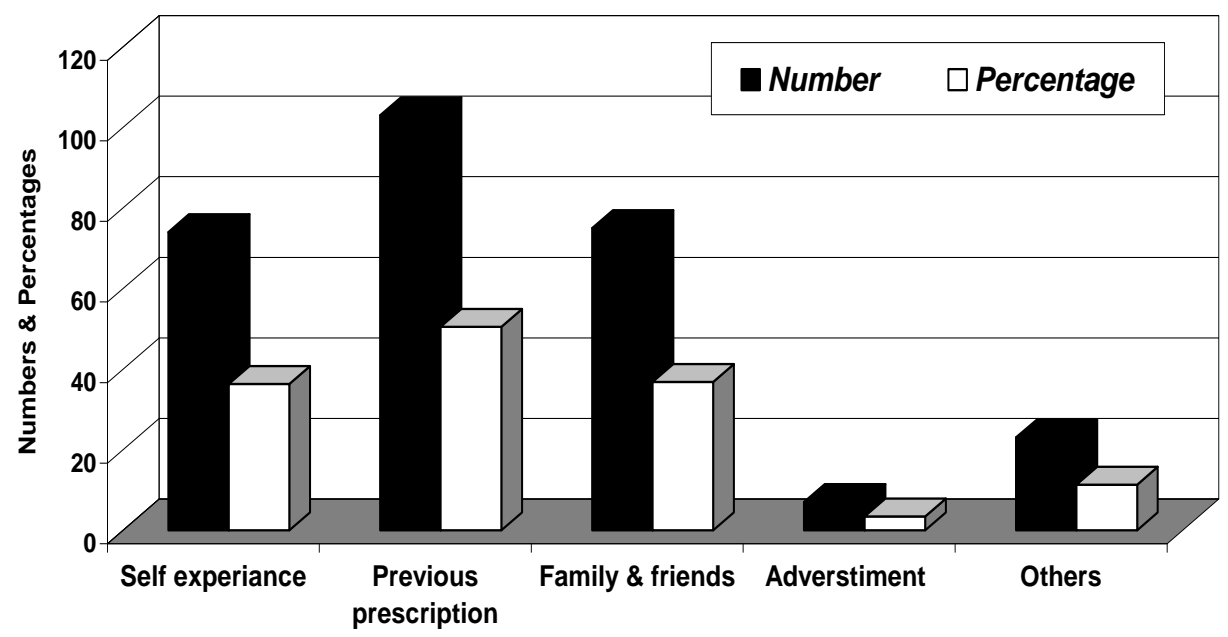

\section{Figure 8. The numbers and percentages of people knowledge about on what basis the patients select the antibiotic.}

\section{Discussion:-}

In our surveyed study (2019), a total of 204 of respondents filled the questionnaire. Majority of respondents (70.1\%) were female. The most of respondents were aged from 19 to 23 years, and over Three-quarters of respondents had university education. About 1264 participants filled the questionnaire; the majority of them $(72.7 \%)$ were female. The most of participants were aged from 34 to 51 years. Just over two-third of respondents had university education. ${ }^{[6]}$ In other research, a total of 306 are participating, $57.2 \%$ are females and nearly equal to the males. Most are adults and their ages varied from 16-29 (47.7\%) and educated at the university or school levels (88.2\%). ${ }^{[9]}$ In other study of Abubaker and Yousif (2015) ${ }^{[10]}$ found that 400 participants were included, $228(57.0 \%)$ of them are males and $291(72.8 \%)$ aged $<40$ year. Other study made by Jorgji et al. (2014) ${ }^{[11]}$ showed residents of town were $379(94.8 \%)$ and university educational level are $303(75.8 \%)$. This study was based on a questionnaire of 3 months duration and includes data from 350 young adults $(182$ men/172 women, mean age \pm SD: $34.72 \pm 13.7$ years).

In our study, the participants were asked if they know what are the antibiotics, $(82.4 \%)$ of them responded with yes, (13.7\%) with may be and only (3.9\%) didn't know. Our study somewhat similar to the study in Bahrain that (97\%) of the participants knew what antibiotics are and only (3\%) didn't have a clue about them. ${ }^{[9]}$ Concerning the source of information about antibiotics, our results found that the majority of participants $(51.9 \%)$ reported the family to be their main source, followed by social media (39.7\%), studying (34.8\%), friends $(26.5 \%)$, books $(15.2 \%)$ and other sources (4\%). A previous study was conducted in Al-Taif (2017), sprung with knowledge of consulting a physician $(62.1 \%)$ is the commonest and most widely used way to gain information about antibiotics, other (17.3\%) of participants informed an advise from a pharmacists was their way to have the information, (12.6\%) of them reported that self-medication was the way to know about the antibiotic used and last but not least (8\%) answered that they used them by an advice of a family member or a friend advice. ${ }^{[12]}$ Another study in Pakistan found that (52.5\%) of participants who received antibiotics without prescription didn't seek an advice from a doctor or health care provider and only $(47.4 \%)$ sought advice. ${ }^{[4]}$ However, Self-medication with antibiotics is made possible via several sources: they are legally available over the counter (OTC); antibiotics initially prescribed by physicians are saved and subsequently used without medical consultation; antibiotics are obtained through friends or relatives, and they can be acquired via Internet. ${ }^{[11]}$

The present study demonstrated the high prevalence of self-medication with antibiotics among the population In Hail. Up to $(14.7 \%),(43.6 \%)$ and $(19.6 \%)$ had always, often or rarely administered unprescribed antibiotics, respectively. While (22.06\%) reported that they never did. A study conducted by Alghadeer et al. (2018) ${ }^{[6]}$ in Saudi Arabia reported the prevalence rate of self-medication with antibiotics as (48.5\%). In another questionnaire-based 
study In Albania, (78.14\%) of the study participants reported that they had received antibiotics without medical prescription at least once in the past 12 months. ${ }^{[11]}$

The finding of this study showed that the main reason for practicing self-medication with antibiotics was for convenience matters $(69.6 \%)$, followed by the high cost of physician's visit $(13 \%)$. While in Sudan, one of the studies reported that the most common cause of self-medication was the simplicity of the condition $(25.9 \%) .{ }^{[14]}$ However, A similar finding to our results was obtained in a local study conducted by Alghadeer et al. (2018) ${ }^{[6]}$ which revealed that $(13 \%)$ of the participants reported the cost of antibiotics as their main reason of self-medication. In the present study, the participants were asked whether they read the instructions labeled with antibiotics or not. Among the participants, $(37.7 \%),(28.4 \%)$ and $(15.7 \%)$ had always, often or rarely read them, respectively. While (18.1\%) reported that they never did, this finding is higher than $13.90 \%$ that reported by Sirijoti et al. (2014) ${ }^{[14]}$. The pamphlet of medicine was designed to guide the consumers to know the ingredients of medicines, instructions of dose, frequency, expiry date, storage method, and the adverse effects. ${ }^{[15]}$ The statistic in our study showed that approximately (49.5\%) of sampled participants said they sometime stop taken antibiotic before complete the course. About $24.5 \%$ of participants said they always stop taken antibiotic before complete the course. While (17.2\%) of participant they seldom stop complete taken antibiotic before complete the course and the $(8.8 \%)$ of them said they never stop taken the course. Comparing with cross-sectional study with questionnaire interviews in Bahraini patients who attended government-funded health centers or private community pharmacies show that $(63.1 \%)$ of them will complete the course of treatment even if they feel better ${ }^{[9]}$ In contrast of our result that reveal poor compliance with antibiotic therapy by rate $(91 \%)$. This practice reflexes the weakness of awareness about antibiotic resistance and would be increased the risk for contracting infections with resistant pathogens.

The statistic in our study showed about why people switch antibiotics during the course of self-treatment said (25.9\%) agree about inefficacy of antibiotic, (13.2\%) agree about adverse effects, (2.5\%) agree about the cost of the drug, and (58.3\%) of people didn't switch the antibiotic. In another study, they said that the participants had also switched over to different antibiotics during the course of self-treatment, figure turns out to be $22 \%$ and $18 \%$ for paramedics and non-medical respectively. While $66 \%$ paramedics and $68 \%$ non-medical respondents do not change to different antibiotics at the time of self-medication with rest of participants who were uncertain. No matter small percentage of participants from both the groups have a practice of switching over to different antibiotics during the period of self-medication, but it could give a significant rise in antibiotic resistance and may also result in spreading of harmful pathogen. ${ }^{[16]}$

The common adverse reactions of antibiotics as nausea (75.4\%), vomiting (63.3\%), diarrhea (58.9\%), rash (59.3\%) , and drug resistance $(76.2 \%) .{ }^{(17)}$ Our result said about the common adverse reactions of antibiotics such as nausea $(62.3 \%)$, vomiting $(25.5 \%)$, diarrhea $(34.3 \%)$, rash $(26.5 \%)$, and others $(12.7 \%)$.

Our study revealed that the reason for antibiotic resistance being take antibiotic without need (23.5\%), don't complete the course of antibiotic (40.2\%), and people don't know (29.9\%). Al-Shibani et al. (2017) ${ }^{[18]}$ summarizes the knowledge of respondents regarding antibiotics resistance and safety. Out of 1966 participants, only (33\%) understand the meaning of antibiotics resistance, (45.8\%) agreed that antibiotics resistance is caused by using unwarranted antibiotics, and incomplete course of antibiotics was (55.4\%). Similarly, in a study by Shehadeh et al. (2012) ${ }^{[19]}$ said one third of the respondents $(38.5 \%$, CI 35.7-41.4) agreed that antibiotics effectiveness would not be affected by antibiotic misuse (defined in this study as not completing the full course of antibiotic), and only $36.0 \%$ agreed that antibiotics would not be effective if they were overused (i.e. using antibiotics when they are not necessary).

Extrapolating from the survey results, most participants were aware that the antibiotic could be harmful of their health since $(77.5 \%)$ of them agree that the antibiotic may affect a patient's immunity. In our study, the matter of why the participants used the antibiotics varies, pharyngitis scored the highest percentage (52.9\%), fever (25.0\%), coughing $(23.5 \%)$ and other $(15.3 \%)$ are respectively subsequent to runny nose and congestion answers that scored (43.6\%) of the percentage. While in a study conducted in Ghana in (2009), the participants reported cold or runny nose to be their most common reason (50.8\%), followed by coughing and/or chest pain $(33.1 \%)$ then stomach ache $(16.9 \%)$ and lastly wounds and foot $\operatorname{rot}(10 \%) \cdot{ }^{[5]}$ Another Albanian study were the participants reported sore throat (29.1\%) and fever $(29.1 \%)$ to be the most common reason followed by cough $(14.7 \%)$, runny nose $(7.1 \%)$ and nasal congestion $(5.2 \%){ }^{[11]}$ 
This study revealed that the main source of information of antibiotics being used without physician's consultation was through previous doctor's prescription (50.5\%), followed by friends and family (36.8\%). Shaghaghi et el. (2014) ${ }^{[20]}$ said that friends, relatives, family, previous prescription by physician, and a pharmacist recommendation are the most frequent source of self-medication worldwide. A similar finding is observed to that reported in Saudi Arabia by rate $(36.6 \%)$ for previous prescription. ${ }^{[6]}$ Moreover, patients may store antibiotics from uncompleted courses, even beyond the expiration date, and later self-administer these drugs for self-diagnosed conditions or dispense them to family members and friends. ${ }^{[21]}$ The role of healthcare providers is to advice the patients not to repeat antibiotic if he/she experience the same symptoms. In some recurrent infections the causative agent may be resistant or acquired resistance during the first course of therapy ${ }^{[10]}$ However, another study show that the most common sources of information on medicines were recommendation of community pharmacists in Taif City in Saudi Arabia by rate $(69.2 \%)^{[10]}$ and in Yemen by rate $(92.3 \%) .{ }^{22]}$ From many studies the pharmacy was the most common source of obtain the antibiotic in different countries in Saudi Arabia $(90.5 \%)^{10]}$, in Egypt $(86.7 \%)^{[23]}$, in Iran $(61.3 \%)^{[24]}$ and Sudan $(72 \%)^{[25]}$. Thus, pharmacists could play an important role in educating patients about antibiotic use in the society. ${ }^{[26]}$

\section{Conclusion:-}

This Study revealed that the prevalence of self-medication with antibiotics in Hail community is high. The majority of illness for which people are seeking self-medication with antibiotics could be probably of viral origin and unnecessary use of antibiotics promote the emergence of new-strains of resistant pathogens and the incidence of unwanted adverse effects.

\section{Recommendations}

Health authorities advised to take serious steps to implement the approved law for no antibiotics without prescription. In addition, health awareness campaigns advised to prevent antibiotic misuse. Also, the pharmacists could play an important role in educating patients about antibiotic use in the society.

\section{References:-}

1. Al-Husein B, Alzoubi F, Masadeh M (2007). Self-Medication with antibiotics in Jordanian population. International Journal of Occupational Medicine and Environmental Health, 20(4):373-80.

2. O'Connor W R, Col F N (1987). Estimating Worldwide Current Antibiotic Usage: Report of Task Force 1. Reviews of infectious diseases, 9(3): 232-43.

3. Morgan D, Okeke I, Laxminarayan R, Weisenberg S (2011). Non-prescription antimicrobial use worldwide: a systematic review. The Lancet Infectious Diseases, 11(9): 692-701.

4. Naveed S, Qamar F, Maqsood A, Ayub A, Kauser H (2015). Prevalence and Consequences of Misuse of Antibiotics, Survey Based Study in Karachi. J Bioequiv Availab, 7:202-204.

5. Tagoe D, Attah q(2009). A Study of antibiotic use and abuse in Ghana. The Internet Journal of Health. 11(12). http://ispub.com/IJH/11/2/6078.

6. Alghadeer S, Aljuaydi K, Babelghaith S, Alhammad A, Alarifi MN (2018). Self-medication with antibiotics in Saudi. Saudi Pharmaceutical Journal, 26(5): 719-724.

7. Zowawi H (2016). Antimicrobial resistance in Saudi Arabia. An urgent call for an immediate action. Saudi medical journal, 37(9):935-940.

8. Aly M, Balkhy H (2012). The prevalence of antimicrobial resistance in clinical isolates from Gulf Corporation Council countries. Antimicrobial Resistance Infection Control, 1(1):26.

9. Alqallaf SM, Winit-Watjana W (2015). Patients' awareness of antibiotic use in Bahraini health centers and community pharmacies. Archives of Pharmacy Practice, 6 (2). https://www.researchgate.net/publication/275258646_

10. Abubaker I and Yousif M (2015). Prevalence, determinants and practices of self-medication with antibiotics - a population-based survey in Taif, Kingdom of Saudi Aarabia. Int J Res Pharm Sci, 5(2): 51 - 56.

11. Jorgji K, Bebeci E, Apostoli P, Apostoli A (2014). Evaluation of use of antibiotics without prescription among young adults in Albania case study: Tirana and Fier District. Hippokratia, 18(3): 217-220.

12. Alkhthami A, Karam R, Abdelrahman T, Al Saeed M (2017). Misuse of antibiotics and antibiotics resistance: A public population-based health survey in AL-Taif - Saudi Arabia. World Journal of Pharmaceutical and Medical Research, 3(2): 54-62.

13. Nour Eldin HS, ELKhawad OA (2014). Self-medication with Antibiotics among Patients Attending Community Pharmacies in Khartoum City. Sudan Journal of Rational Use of Medicine,6:14-15 
14. Sirijoti K, Hongsranagon P, Havanond P, Pannoi W (2014). Assessment of knowledge attitude and practices regarding antibiotic use in Trang province, Thailand. Journal of health research, 28(5): 299-307.

15. Brown-Brumfield D, DeLeon A (2010). Adherence to a medication safety protocol: current practice for labeling medications and solutions on the sterile field. AORN J, 91(5): 610-7.

16. Narzaree P, Guptaet M C (2016). Knowledge towards antibiotic usage among paramedics and nonmedical personnels of a tertiary care hospital. International Journal of Basic \& Clinical Pharmacology, 5(5):1929-1936.

17. Zhu X, Pan H, Yang Z, Cui B, Zhang D, Ba-Thein W (2015). Self-medication practices with antibiotics among Chinese university students. Public health, 130: 78-83.

18. Al-Shibani N, Hamed A, Labban N, Al-Kattan R, Al-Otaibi H, Alfadda S (2017). Knowledge, attitude and practice of antibiotic use and misuse among adults in Riyadh, Saudi Arabia. Saudi Med J, 38(10): 1038-1044.

19. Shehadeh M, Suaifan G, Darwish RM, Wazaify M, Zaru L, Alja'fari S (2012). Knowledge, attitudes and behavior regarding antibiotics use and misuse among adults in the community of Jordan. A pilot study. Saudi Pharm J, 20(2):125-33.

20. Shaghaghi A, Asadi M, Allahverdipour H (2014). Predictors of Self-Medication Behavior: A Systematic Review. Iranian J. Pub. Health, 43(2): 136-146.

21. Belkina T, Alwarafi A, Eltom EH, Tadjieva N, Kubena A, Vlcek J (2014). Antibiotic use and knowledge in the community of Yemen, Saudi Arabia, and Uzbekistan. J Infect Dev Ctries, 8(4): 424-429.

22. Albawani SM, Hassan Y, Abd-aziz N, Gnanasan S (2017). Self-medication with antibiotics in Sana'a City, Yemen. Trop J Pharm Res, 16(5): 1195-1199.

23. Ghazawy ER, Hassan EE, Mohamed ES, Emam SA (2017). Self-Medication among Adults in Minia, Egypt: A Cross Sectional Community-Based Study. Health, 9: 883-895.

24. Heidarifar R, Koohbor M, Kazemian Mansourabad M, Mikaili P, Sarahroodi S (2013). Self-medication with Antibiotics among Iranian Population in Qom State. Journal of Scientific and Innovative Research, 2(4): 785789.

25. Elhada AH, Eltayeb IB, Mudawi MM (2014). Pattern of self-medication with antibiotics in khartoum state, Sudan. World Journal of Pharmaceutical Research, 3(5): 678-692.

26. Alhomouda F, Aljameaa Z, Almahasnaha R, Alkhalifaha K, Basalelaha L, Alhomoud Fk (2017). Selfmedication and self-prescription with antibiotics in the Middle East do they really happen? A systematic review of the prevalence, possible reasons, and outcomes. International Journal of Infectious Diseases,57:3-12 